\title{
Acute Kidney Injury Due to Leukemic Infiltration in a Patient with Chronic Lymphocytic Leukemia
}

\author{
Kronik Lenfositik Lösemide Lösemik Infiltrasyona Bağlı Akut Böbrek Yetmezliği
}

(D) Gizem Kumru Şahin1, (D) Hasan Emre Kocabay2, (D) Saba Kiremitçi3, (D) Osman İlhan4, (D) Kenan Keven1

${ }^{1}$ Ankara University Faculty of Medicine, Department of Nephrology, Ankara, Turkey

${ }^{2}$ Ankara University Faculty of Medicine, Department of Internal Medicine, Ankara, Turkey

${ }^{3}$ Ankara University Faculty of Medicine, Department of Medical Pathology, Ankara, Turkey

${ }^{4}$ Ankara University Faculty of Medicine, Department of Hematology, Ankara, Turkey

\section{To the Editor,}

The kidneys are among the organs most affected by leukemic involvement in chronic lymphocytic leukemia (CLL) patients in postmortem autopsy series (63\%-90\%) [1,2]. However, leukemic infiltration (LI) of the kidneys has been a rare cause of renal impairment in CLL patients [3,4]. Here we describe a case of CLL presenting with severe acute kidney injury (AKI) due to LI.

A 72-year-old white male without any renal disease presented with general malaise and weight loss. He had been diagnosed with stage $\mathrm{B}(1) \mathrm{B}-\mathrm{CLL}$ four years before and was treated with a bendamustine and rituximab protocol. Physical examination revealed general lymphadenopathy and hepatomegaly. Complete blood count findings were as follows: hemoglobin, $11.3 \mathrm{~g} / \mathrm{dL}$; leukocytes, 411.4x109/L (lymphocytes: 60\%); platelets, 247×109/L. The blood film appearances were suggestive of CLL. The following biochemical tests were abnormal: blood urea nitrogen, $44 \mathrm{mg} / \mathrm{dL}$ (normal: 8-22); serum creatinine $(\mathrm{sCr}$ ), $6.16 \mathrm{mg} / \mathrm{dL}$ (normal: 0.7-1.3); CKD-EPI estimated-glomerular filtration rate, $8 \mathrm{~mL} / \mathrm{min} / 1.73 \mathrm{~m}^{2}$ (normal: $>60$ ). His urine had no leukocytes or casts, with 3 erythrocytes/field and proteinuria in the non-nephrotic range $(1779 \mathrm{mg} / 24 \mathrm{~h})$. Serological tests for hepatitis B, hepatitis C, HIV, and autoimmune kidney disorders were negative. Serum-free light chain (sFLC) kappa was $317.5 \mathrm{mg} / \mathrm{dL}$ (normal: $3.3-19.4$ ) and $\mathrm{sFLC}$ lambda was $22.2 \mathrm{mg} / \mathrm{dL}$ (normal: 5.71-26.3), but no monoclonal bands in serum or urine immunofixation were detected. Renal ultrasound showed normal-sized kidneys with no evidence of obstructive nephropathy. A renal biopsy was performed, which demonstrated heavy infiltration of diffuse monomorphic neoplastic lymphocytes in the interstitium (Figure 1A). Six of 21 glomeruli were globally sclerotic and acute tubular necrosis and disruption were seen. Immunohistochemistry revealed that these infiltrative cells were positive for CD20 and CD5 (Figures $1 \mathrm{~B}$ and $1 \mathrm{C}$ ) without any amyloid or light chain deposition. The clinical picture was consistent with AKI due to LI of the kidneys. Therapeutic leukapheresis and treatment with highdose methylprednisolone and rituximab were administered. His renal functions were restored with no need to perform hemodialysis and complete response in CLL was achieved (leukocytes: $10.3 \times 10^{9} / \mathrm{L}$ ). After a year of follow-up, his renal function had improved to $\mathrm{sCr}$ of $2.04 \mathrm{mg} / \mathrm{dL}$, and a complete blood count revealed hemoglobin of $14.7 \mathrm{~g} / \mathrm{dL}$, leukocytes of $9.15 \times 10^{9} / \mathrm{L}$, and platelets of $294 \times 10^{9} / \mathrm{L}$.

Besides LI, renal impairment in CLL patients can be associated with prerenal azotemia, thrombotic microangiopathy, acute tubular necrosis, acute interstitial nephritis, uric acid nephropathy, light chain nephropathy, amyloidosis, obstructive nephropathy, glomerulonephritis, and cryoglobulinemia [5]. LI of the kidneys is common in CLL, but it is unlikely to be associated with severe AKI [4]. Although the mechanism of this clinical presentation is unclear, it was suggested that the compression of the tubular lumen and microvasculature by CLL cells may cause intrarenal obstruction and ischemia [6]. No clear association was demonstrated between CLL stage, intensity of interstitial infiltration, and severity of renal impairment [7]. Relapsed or refractory $\mathrm{CLL}$ and presentation with $\mathrm{AKI}$ are supportive for $\mathrm{LI}$
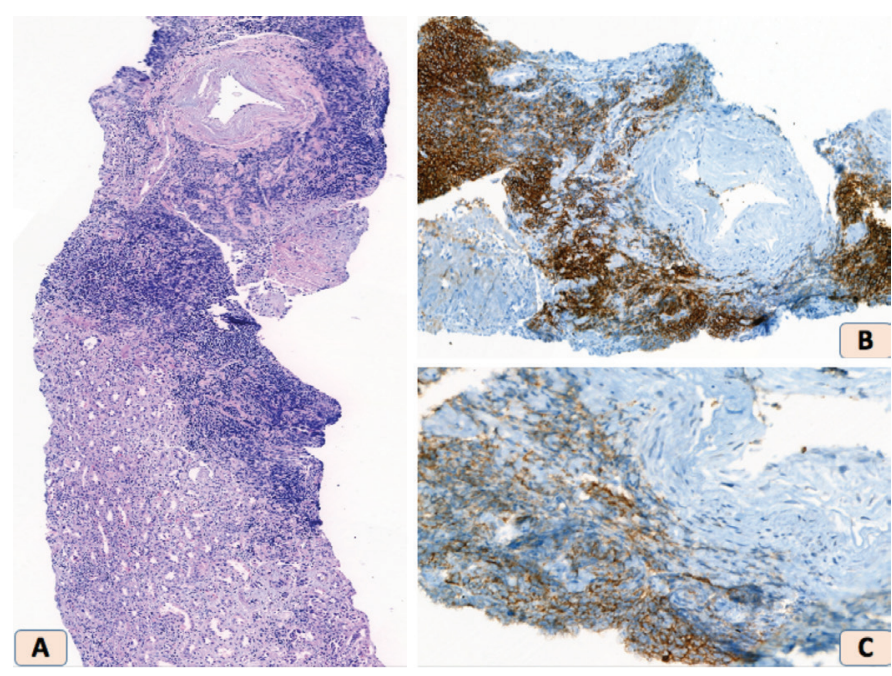

Figure 1. (A) Diffuse monomorphic neoplastic lymphocytic infiltrate in the renal tissue (H\&E, 200x). (B) Lymphocytic infiltration showing immunopositivity for CD20 (immunohistochemistry, $300 x)$. (C) Lymphocytic infiltration showing immunopositivity for CD5 (immunohistochemistry, 300x). 
as the primary cause of renal impairment [6,8]. After exclusion of other causes, kidney biopsy should be performed to confirm the diagnosis. Significant improvement in renal function was reported after CLL treatment in a majority of patients $[8,9]$. Our case shows that $\mathrm{LI}$ of the kidneys can cause AKI as the initial manifestation of CLL and physicians should be aware of the atypical presentations of the disease.

Keywords: Acute kidney injury, Chronic lymphocytic leukemia, Leukemic infiltration

Anahtar Sözcükler: Akut böbrek yetmezliği, Kronik lenfositik lösemi, Lösemik infiltrasyon

\section{Ethics}

Informed Consent: Informed consent was obtained from the patient included in the study.

\section{Authorship Contributions}

Medical Practices: G.K.Ş., H.E.K., S.K.; Concept: G.K.Ş., O.I., K.K.; Design: G.K.Ş., O.I., K.K.; Data Collection or Processing: G.K.Ş., H.E.K., S.K.; Analysis or Interpretation: G.K.Ş., K.K.; Literature Search: G.K.Ş.; Writing: G.K.Ş.

Conflict of Interest: No conflict of interest was declared by the authors.

Financial Disclosure: The authors declare that this study received no financial support.

\section{References}

1. Barcos M, Lane W, Gomez GA, Han T, Freeman A, Preisler H, Henderson E. An autopsy study of 1206 acute and chronic leukemias (1958 to 1982). Cancer 1987;60:827-837.

2. Schwartz J, Shamsuddin A. The effects of leukemic infiltrates in various organs in chronic lymphocytic leukemia. Hum Pathol 1981;12:432-440.

3. Da'as N, Polliack A, Cohen Y, Amir G, Darmon D, Kleinman Y, Goldfarb AW, Ben-Yehuda D. Kidney involvement and renal manifestations in nonHodgkin's lymphoma and lymphocytic leukemia: a retrospective study in 700 patients. Eur J Haematol 2001;67:158-164.

4. Shanafelt TD, Rabe KG, Hanson CA, Call TG, Schwager S, Parikh SA, Nasr H, Leung N. Renal disease in patients with chronic lymphocytic leukemia (CLL). Blood 2013;122:5302 (abstract).

5. Wanchoo R, Ramirez C, Barrientos J, Jhaveri K. Renal involvement in chronic lymphocytic leukemia. Clin Kidney J 2018;11:670-680.

6. Kowalewska J, Nicosia RF, Smith KD, Kats A, Alpers CE. Patterns of glomerular injury in kidneys infiltrated by lymphoplasmacytic neoplasms. Hum Pathol 2011;42:896-903.

7. Poitou-Verkinder AL, Francois $A$, Drieux $F$, Lepretre $S$, Legallicier $B$, Moulin B, Godin M, Guerrot D. The spectrum of kidney pathology in B-cell chronic lymphocytic leukemia / small lymphocytic lymphoma: a 25-year multicenter experience. PLoS One 2015;10:e0119156.

8. Strati P, Nasr SH, Leung N, Hanson CA, Chaffee KG, Schwager SM, Achenbach SJ, Call TG, Parikh SA, Ding W, Kay NE, Shanafelt TD. Renal complications in chronic lymphocytic leukemia and monoclonal B-cell lymphocytosis: the Mayo Clinic experience. Haematologica 2015;100:1180-1188.

9. Uprety D, Peterson A, Shah BK. Renal failure secondary to leukemic infiltration of kidneys in CLL - A case report and review of literature. Ann Hematol 2013;92:271-273. 